\title{
Internal Factors on Resource Control Saga in the Nigera Delta and Their Impact
}

\author{
Adeoti, Ezekiel Oladele ${ }^{1}$, Imuoh Austen ${ }^{2}$ \\ Faculty of Arts, Department of History and International Studies Lagos State University, Ojo, Lagos, Nigeria \\ Department of History, University of Ibadan, Ibadan, Nigeria
}

\begin{abstract}
The quest for resource control by states in the Niger Delta region is one of the contentious issues in Nigeria. The clamour for resource control followed the inability of the government to address the adverse social and economic conditions under which the people of the Delta region have been forced to live since the discovery of oil at Oloibiri in 1956. The exploration and production of oil and their concomitant negative effects have continued to affect the people's agricultural and fishing activities. Pollution and gas flaring have continued to wreak havoc on the people's means of livelihood while the love for money as well as the desire to live above poverty line in the Niger Delta have forced many into all kinds of obnoxious practices such as illegal oil bunkering cum illegal oil refining, militancy, distruption of the activities of oil companies operating in the area; kidnapping of oil workers with demands for ransom and vandalization of petroleum facilities to cause spillage of which communities would demand compensation. This study examines the quest for resource control by people in the Niger Delta region, and the negative impact of this development on both Niger Delta people in particular and Nigerian state in general. Finally, the work concludes by suggesting the possible ways for peace to reign in the troubled region. The work adopts the descriptive and analytical method of historical discourse as the framework of analysis.
\end{abstract}

Keywords: Niger Delta, Resource Control, Ogori, Ijaw Youth Council, MOSOP

\section{INTRODUCTION}

The Niger Delta region of Nigeria measures about 70,000 square kilometres and occupies the southern part of the country (Sunday Sun, 11 June, 2006:7). With a population of about 21 million, the Delta region is home to the nine oil-producing states in Nigeria including Delta, Bayelsa, Rivers, Cross-River, Akwa Ibom, Edo, Ondo, Imo and Abia States (Sunday Sun, 11 June, 2006:7). The region also boasts of multi-ethnic nationalities namely Ijaw, Kalabari, Ndoni, Efik, Annang, Ibolo, Itsekiri, Edo, Urhobo and many others (ObI C., 1999). Broadly speaking, the Delta region comprises about 300 communities each with its own dialect. About 2.3 million barrels of Nigeria's daily oil production comes from the Delta region which also has a gas reserve of about 160 million cubit feet and oil reserve of about 3.0 million barrels (Tell Magazine, 7 April, 2003).

Nigeria accounts for about 25 billion barrels out of Africa's 66 billion barrels proven reserve with a large chunk of the country's oil resources located in the Delta region (Idehen, R.O. 2008:462). Economically, oil produced in the Niger Delta accounts for about 80 percent of Nigeria's Gross Domestic Product and 90 percent of national budget (Ogbogbo, CBN 2005:169) . Apart from oil and gas, the Delta region also boasts of minerals such as iron ore, bauxite among others (Adeyemo, T.K. 2008:21). However, the crave for petro-dollar which came with the evolution of the oil industry in Nigeria has relegated the exploration of other vital minerals in the Delta region to the background.

The discovery and exploitation of the abundant mineral and natural resources in the Niger Delta began with the advent of Europeans in many parts of Africa including Nigeria in the $15^{\text {th }}$ century. Indeed, from 1472 (when the first set of Europeans landed in the Delta region) up to the Berlin Conference of 1884-1885 (Ahmed, D.L. 2006:14), the Delta region like other parts of Nigeria was the centre of competition by the various European companies and individuals for the exploitation of the region's mineral and natural resources. Significantly too, this period also marked the integration of the economy of the Delta region into the capitalist enclave which further ensured the continued exploitation of the mineral and natural resources of the region by European powers. Similarly, the Delta region was not spared of the 'holocaust' of the slave trade era, which saw able-bodied peoples of the Delta region

${ }^{1}$ Corresponding Author:deleadeoti@gmail.com 
taken to the New World where they worked in sugar plantations under inhuman conditions (Ahmed, D.L. 2006:14). The unsavoury tale in the development of human and material resources of the Delta region continued with the emergence of colonialism in the 1900s, and the establishment of the Oil Rivers Protectorate in the 1890s (Ahmed, D.L. 2006:14). The amalgamations of 1906, and 1914 completed the process of British colonisation of Nigeria, which tied the economy of Nigeria (including the Delta region) to that of metropolitan Britain. During the over 100 years of colonial rule, the mineral and natural resources of the over 308 independent kingdoms, empires or vassalages were pillaged and appropriated for the benefit of the metropolitan power (Ahmed, D.L. 2006:14). The bulk of these resources exploited by the British came from the Delta region.

Nevertheless, the end of colonialism in Nigeria in 1960 and the emergence of oil as the mainstay of the Nigerian economy in the post independence years further worsened the wound inflicted on the Niger Delta people by European colonisers. Until the advent of oil as the pivot of the Nigerian economy, the country depended on cocoa, palm oil, groundnut, rubber, among others as its main sources of exports. Indeed, in the immediate postindependence era, agriculture was the cornerstone of the Nigerian economy, employing about 70 percent of the country's total labour force. The huge attention paid to oil as the pillar of Nigeria's economy in the post-independent years as mentioned previously brought unsavoury conditions to the people of the Delta region which accommodates about 95 percent of the country's oil and gas reserves. Currently, there are over eleven oil companies operating more than 158 oil fields and about 1,481 oil wells in the Delta region with ugly indices such as gas flaring and oil spills (The Guardian, June 13, 2006:16). Between 1976 and 1999, a total of 3,000 oil spill incidents were recorded by all the oil companies operating in the Delta region, with over two million barrels of oil spillage into Nigeria's terrestrial, coastal and offshore marine environments (Agbu, O., 2005:82-83). With respect to gas flaring, statistics also show that about 24,240,000 sef of gas was flared in 1991 alone. This is the equivalent of 76 percent of gross production of oil in Nigeria during the same year. By 1995, the percentage of gas flared had increased to 76.79 percent (Nyemutu, R., (n.d) :33) .

\section{The Struggle For Resource Control In The Niger Delta Region}

The demand for resource control can aptly be described as the new face of nationalism in the Niger Delta region. The new nationalism centres around secession from the Nigerian state by states in the Niger Delta. The term resource control was first used at the third forum of governors of oil producing states in 1999 and defined as:

The practice of true federalism and natural law in which the federating units express their rights to primarily control the natural resources within their borders and make agreed contribution towards the maintenance of common services of the government at the centre (Azaiki, S. 2006:296).

This definition reflects strongly the provisions of the 1958, 1960 and 1963 constitutions which granted fiscal autonomy to the four regions that made up Nigeria namely the west, east, north and mid-west. Fiscal autonomy or fiscal federation conveys on all the states in Nigeria the power to control and manage their natural and mineral resources while also contributing a certain percentage of their earnings to the central government as prescribed in the Nigerian constitution (Azaiki, S. 2006:296). In practice, the central government determines the percentage of revenue that accrues to oil producing areas including the Niger Delta region.

The Delta region conflict which began in the 1960s and continued through the 1990s and even beyond was influenced by the degrading conditions of the people of the Delta region, the failure of governments and their agencies to improve and develop socio-economic infrastructure in the region, massive diversion of funds meant for the development of the region to other areas by government officials, worsening economic conditions after the introduction of Structural Adjustment Programme (SAP) in 1986, youth restiveness occasioned by the lack of employment opportunities in the Delta region, among others.

Previous attempts by government to improve the social and economic conditions of the Delta region through such institutions as the Niger Delta Development Board (NDDB), the Niger Delta Rivers Basin Development Authority, the Oil Mineral Producing Area Development Commission (OMPADEC), Association of Mineral Oil States (AMOS) and the Niger Delta Development Commission (NDDC) also failed due to reasons ranging from inadequate funding to corruption and embezzlement of funds by officials. For example and apart from alleged diversion of funds from the agencies for personal uses, both the OMPADEC and NNDC were known to have suffered greatly from insufficient funding which made the accomplishment of their assignments difficult. Indeed while OMPADEC was riddled with massive corruption and embezzlement by both leadership and officials, Obasanjo's NDDC was also starved of funds to fulfil its responsibilities to the Niger Delta people. For example, while the NDDC Act required the federal government to contribute a mandatory 15 percent equivalent of the statutory allocation to oil 
producing states to the commission, it only released 10 percent of the funds, leaving a 5 percent shortfall (Azaiki, S. 2006:309-310). Indeed, under the Obasanjo administration it took a lot of political brinkmanship in lobbying, pandering, personal contacts and in most cases outright begging for the government to release funds to the NDDC (Ahmed, D.L. 2006:21).

The lacklustre attitude of governments towards the development of the Delta region increased tension and anxiety in the region and accounted largely for the emergence of several organisations, some of which became the catalyst of resource control in Niger Delta. While some of these organisations professed and adopted dialogue as a means of attaining their goals, others chose violent approach. In the first category are movements such as Ethnic Minority Rights Organisation, The Ethnic Rights Organisation of Africa, the Movement for Reparation to Ogbia or Oloibiri, Movement for National Reformation, the Southern Minorities Movement. These organisations made ample use of conferences, workshops, media and dialogue with the federal government to press home their demand for resource control in Nigeria.

However, this liberal group could not go beyond these forms of protest because the political milieu, for the greater part of the period during which the country was under military rule, did not present opportunity for a more forceful approach to demands or equity, justice and fair play. The experience of Isaac Adaka Boro, who attempted secession in the wake of the 1966 military coup, who ended up in jail and the crisis which engulfed Ogoniland in the 1990s, which culminated in the death of 13 prominent chiefs and sons of the community, was enough proof of the consequence of making the right demands at the wrong time.

Members of the second category consisted of militant organisations or movements. Members in this class believed in the use of force or militancy or protest to achieve their aim of managing and controlling their natural and mineral resources. Although founded on the pillars of the Major Isaac Boro revolution of 1966, by 1999 militancy had become the most preferred weapon of achieving the goal of resource control in the region. The atmosphere was perhaps riped for it because the advent of democratic governance in 1999 naturally brought with it the various freedoms associated with democracy, including freedom of expression.

Soon after the inauguration of the Fourth Republic in 1999, agitations in the Niger Delta shifted from demands for a fair share of the national cake to the right to have control over natural resources that are found in the region.

Protagonists of resource control pushed forward the argument that the country cannot be said to be a federation when the elements of federation such as state police, control of natural resources by the federating units and state electoral bodies are lacking. Their argument was based on the precedence during the First Republic (1960-1966) when the 4 regions which were then the federating units had control over agricultural produce. This was at a time when agriculture was the mainstay of the Nigerian economy.

The 3 major regions - Eastern, Western and Northern - had control of palm produce, cocoa and groundnuts, respectively. Beside this, the regions also got as high as 50 percent derivation from whatever accrued to the Federation account as revenue from the agricultural produce. It may have been agreeable in the 60s because the monies that accrued to the regions could not be compared with what oil -bearing states would get today. Apart from that, major beneficiaries of that arrangement were the Igbo, Yoruba and Hausa/Fulani who dominated Nigerian politics then. Nigerian politics then (Azaiki, S., 2006:127). The situation is different today as potential beneficiaries of 50 percent derivation are minorities whose voice, even if collective, is feeble and hardly have much or instant impact in a major policy such as this. However, the people of the Niger Delta found it unjustifiable and therefore unacceptable, that along the line, the practice was abandoned, while derivation was reduced to mere 3 percent. It was only hiked to 13 percent on 29 May, 1999.

The agitation for resource control is naturally tied to the demand for the control of land. The Niger Delta people were quick to point to other parts of the country particularly the North as a good example where traditional rulers hold land in trust for the people. They averred that the practice was the same in the Niger Delta right from ancient time until oil was discovered in the region. They could not understand why the Federal Government came out with the various laws and legislations enacted between 1967 and 1997 to confiscate their land from them.

Indeed, militant movements were founded at various times and in many communities in the Delta region all with the objective of managing and controlling their resources in line with true fiscal federalism. Prominent militant organisations formed in the 1990s include the Movement for the Survival of Ogoni People (MOSOP); the Ijaw Youth Council (IYC), Niger Delta People Volunteer Force (NDPVF), Supreme Egbe (Assembly (SEA); Niger Delta United Force (NDUF), Movement for the Emancipation of the Niger Delta (MEND), Coalition of Militant Actions in the Niger Delta (COMA) (Daily Champion 25 Jan. 2011). These groups engaged in pipeline vandalism, 
kidnapping, hostage-taking and abductions in their operations. Buoyed by the presence of sophisticated weapons at their disposal, these armed groups were no longer content with resource control but resurrected the old ideas of ultimate sovereignty for the whole of the Delta region. Massive destruction of oil pipelines, kidnappings and abductions perpetrated by some of these militant groups against the foreign oil companies and expatriate working in the Delta region eclipsed the struggle by moderate organisations or movements which were also dedicated to the project of resource control.

Elsewhere, youths who were not members of either the civilian or militant organisations also formed themselves into groups to protest against the insensitivity of the government and the oil companies to address their problems. One of the most prominent protests against the multinational oil corporations took place at Umuechem on 30 and 31 October 1990 (Nsirimovu, A., 1994). Specifically, the protest was targeted at the Shell Petroleum Developing Corporation which had earlier overlooked request by the people of the area for the provision of electricity, water and roads to compensate for the massive destruction of their farmlands and fishing waters. At the end of the protest, about eight protesters were killed and 495 houses destroyed by the mobile policemen who were called to quell the protest by the SPDC (The Nigerian Army Quarterly Journal, 2008:468). The action of the mobile police was sequel to the missing of three of their colleagues who were alleged to have been killed by the community on the first day of the protest (Nsirimovu, A., 1994). The killings and destructions that took place in Umuechem did not deter further protests in other Delta communities. If anything, they increased the people's hatred for the oil corporations and the federal government in the Delta region. A few years after the Umuechem disaster the peoples of Ighide and Uzere (Ogbogbo, CBN: 2005) took to the streets in protest against SPDC's non-committal attitude to the provision of basic amenities to its host communities. However, unlike Umuechem, the protests at Ighide and Uzere ended after a series of negotiations with the SPDC(Ogbogbo, CBN: 2005). The recourse to negotiations rather than repression may not be unconnected with the criticisms and vilifications that trailed the action of the mobile policemen at Umuechem.

A significant aspect of the quest for resource control is the involvement of women. In many villages and towns in the Delta region, women took the centre stage in the clamour for resource control. At various towns, women and children from Delta communities such as Ugbovodo and Gbaramutie invaded and took over Chevron's tank farm and terminal in Escavos, as well as the Nigerian National Petroleum Corporation/Chevron flow stations in Niger Delta swamps (Ogbogbo, CBN: 2005) demanding for justice in the management and control of their resources.

Similarly, women in Warri also organised themselves under the Women Consultative Assembly and in 2002 threatened to seal off all oil wells in the Delta region (Ugo, C.S., 68). Although that did not happen, the threat showed that the Niger Delta women were no longer prepared to take the back seat in the struggle for the control of resources by states in the Delta region.

\subsection{An Assessment of the Impact of the Clamour for Resource Control on the Niger Delta and the Nigerian State.}

Until very recently, the conflict in the Niger Delta was the most protracted in Nigeria. The crisis was exacerbated in part by the lacklustre attitude of both the federal government and its interventionist agencies such as the OMPADEC and NDDC to address the social and economic problems affecting the Niger Delta people following several years of oil exploration in the region. Indeed, the discovery of oil which ordinarily should be a source of joy for the people of the Delta region became the means of not only pauperising them but also jeopardizing the future of their children and even the unborn ones.

Oil exploration comes with various negative consequences such as contamination of farmlands and water, noise and environmental pollution, deforestation and destruction of the ecosystem. In the Niger Delta as in other areas where oil exploration takes place, the people's farming and fishing occupations are disrupted due to gas flaring and oil spillage. Similarly, noise emanating from continuous oil drilling and oil spillage has destroyed the biological and eco-system of the Delta region while the laying of oil pipes has deforested most of the lands in the region (Adejumobi, 2002). Moreover, oil exploration produces poisonous gases such as carbon monoxide, chlorine, nitrogen oxides, sulphur oxides, acid aerosol, beryllium among others which are not only harmful to the environment but also to the people who live in the region. Common diseases in the Delta region such as heart problem, irritations, oedema, dizziness and lots more have been ascribed to the above mentioned harmful substances (Idehen R.O. 2008:461). This problem is worsened by lack of effective medical facilities in the region.

Indeed, lack of basic facilities for the use of the people is just an aspect of the poor or squalid social and economic infrastructure in the area. A World Bank report in 1995 revealed startling indices of the living conditions prevalent among the people in the Niger Delta region. According to the report, Bayelsa State of all the states that make up the 
Delta region had the worst cases of water borne diseases, and high infant mortality while the means of transport and communication were in deplorable conditions. The report also painted a gloomy picture of education and the absence of basic infrastructure such as electricity, pipe-borne water, housing among others in some Delta communities like Ogoni. The report also revealed that even in communities where health facilities were in existence, there were barely adequate medical staff to cater for the sick (Idehen, R.O., 2008:461).

The struggle led to the rise of all manner of community leaders, all claiming to represent their communities, but actually working to satisfy their selfish interests. These people do not actually reside in the communities, which they claim to lead. Most of them are domiciled in urban centres, far away from the negative effects of the activities of oil companies. Until very recently, it was common practice for these self-styled leaders to misappropriate compensations or donations, which oil companies ignorantly doled out through them to the communities. This development greatly damaged the relationship between the oil companies and their poor host communities which ultimately culminated in the kidnapping and killing of oil workers and vandalization of oil pipelines (Ekpo, Udeme, 200:149).

Apart from economic and social instability, the clamour for resource control in the Delta region also has had serious consequences for peace and stability of the Nigerian state. Many prominent indigenes of the area and outside have lost their lives to the struggle for resource control in the Delta region. The killing of Ken Saro Wiwa, a renowned and world's celebrated environmental campaigner and playwright in 1995 is a significant example of federal government's repressive acts against activists in the region (Ahmed, D.L. 2006: 26). Saro Wiwa was found guilty of contributing to the murder of fellow Ogoni activists who were neither members nor supporters of the MOSOP's campaign for resource control. By the time General Sani Abacha died in office in 1998, about one thousand Ogoni indigenes had been killed by Abacha's security goons while scores of Ogoni indigenes were dumped into detention for their role in the struggle for resource control. Similarly, the vicious attacks on the Delta communities of Umuchem and Odi during the Olusegun Obasanjo civilian administration as a result of protests over poor state of infrastructures in the communities left many people killed or maimed. Apart from sacking the whole communities, Obasanjo's security agents were reported to have carried out acts of rape and torture against women and men of Odi community specifically (Ahmed, D.L., 2006:26)

Perhaps, the biggest loser in the clamour for resource control was the Nigerian economy. Owing largely to the operative methods of the militants in the region such as pipeline vandalism, rig blockages, hostage taking and illegal oil bunkering, the Nigerian economy suffered tremendous hiccups particularly in the 1990s when ethnic militancy got to the hilt in the Delta region. About seventy-five oil spillages which occurred in the Delta region in the 1990s were attributed to militant activities. The impact of the militant activities on the Nigerian economy was visible. About one billion dollars was lost following coordinated attacks on oil facilities in the region in February 18, 1996 (Ogbogbo, CBN 2005:176).

Additionally, several billions of dollars were lost on yearly basis due to stalled operations of exploration since the target of the militants were the expatriates and "bourgeoisie" oil firms in the region. The Shell Petroleum Development Corporation (SPDC) reported a loss of about \$1.4 million as a result of pipe-line vandalism in 1992 and a drop to about $\$ 900,000$ in oil revenue the following year (The Punch, 21 March, 2008:39). All this happened in the corporations western division alone. The loss in the company's eastern division is higher than in the west. The company estimated a loss of 1,269 men-days and N250.4 million in its western division in 1993 (Ogbogbo, CBN 2005: 176).

The struggle for resource control was also a major threat to the security of the country. The possession of sophisticated weapons like Russian-made AK-47, grenades and dynamites by the militants threatened not only peace and security in Nigeria but in neighbouring West African countries. The high wave of armed robbery incidents that accompanied militancy in the Delta region and even in neighbouring states like Edo disrupted free movement of people and goods from other parts of Nigeria to the Delta area.

The proliferation of weapons and various militant activities in the Niger Delta also cast a big shadow on Nigeria's external image (Ogbogbo, CBN: 2005:177). The United States of America, for example, issued several travel warnings to its citizens not to go to Nigeria as a result of insecurity caused by the conflict in the Delta region. Although such calls did not significantly affect Nigeria - USA bilateral socio-political and economic relations, there is no doubt that it went a long way in denting the image of Nigeria in the comity of nations, thus contributing to its unenviable status as a "pariah" nation. 


\section{CONCLUSION}

The struggle for resource control in the Niger Delta has been due largely to the inability of the federal government to implement a true fiscal federalism that would enable states in the Niger Delta region and other states in Nigeria to develop and control their mineral and natural resources. Yet the use of force by the Niger Delta militants and the federal government to resolve the conflict brought untold hardship on the local people, expatriates, multinational oil corporations and more importantly the Nigerian economy. Moreover, the use of light automatic weapons like AK47, grenades and dynamites by the Delta militants portray Nigeria as a country at war with itself in the eye of the international community as majority of oil prospecting companies in the region come from the western world. Despite recent attempts at resolving the Delta conflict through the amnesty programme, the fact that majority of the Delta people are still poor makes the resurrection of militancy in the region possibility.

As a way forward out of this impasse, it is hereby suggested that, firstly, there should be increase in the social responsibility activities of oil companies as well as increase in government spending on development programmes in the Niger Delta area. Secondly, there should be an increase $\mathrm{n}$ revenue allocation base don derivation, from the present 13 percent to 50 percent. An increase in derivation to 50 percent would give more money to oil-bearing states. With more money at their disposal, the negative effect of oil exploration and production would be effectively taken care of.

Another way forward is to make oil-bearing states active stake-holders on the business of oil exploration and production. This is to ensure that communities where oil is found, where the activities of oil companies are carried out, where negative effects of those activities are felt most, are adequately compensated. All these would bring about enduring peace in the region.

\section{REFERENCES}

[1] Okah, E. (2006), "Niger Delta: A Cradle of Violence”, (Sunday Sun, (Lagos), June 11, 7).

[2] (Sunday Sun, (Lagos), June 11, 2006: 7).

[3] Obi, C. (1999), "Oil, Environmental Conflict in the Niger Delta" The Quarterly Journal of Administration, Vol. XXX, 384, September 1998 - January 1999.

[4] Omene, G. (2013), “The NDDC is Transforming the Region” Tell Magazine (Lagos), No. 14, April 7,).

[5] Idehen, R.O. (2008), "Militancy in the Niger Delta: Implication for Nigeria's National and Sub-Regional Security" The Nigerian Army Quarterly Journal, Vol. 4, No. 4, December 2008,

[6] Ogbogbo, C.B.N. (2005), "The Niger Delta Peoples and the Resource Control Conflict 1960-1995: An Assessment of Conflict Handling Styles" in Olawale, Albert (ed.), 2005, Perspectives on Peace and Conflict in Africa: Essays in Honour of General (Dr) Abdul Salami Abubakar (Peace and Conflict Studies Programme, Institute of African Studies, University of Ibadan, Ibadan, Nigeria.

[7] Adeyemo, T.K. (2008), "The Seigbein Festival among the Kabowei Ijaw People of Bayelsa State", B.A. Project Essay, Department of History and International Studies, Lagos State University.

[8] Ahmed, D.L. (2006), “A History of Resource Control in the Niger Delta, 1995-2005” B.A. Project Essay Department of History and International Studies of Lagos State University.

[9] The Guardian (Lagos), 13 June, 2006, 16.

[10] Agbu, O. (2005), "Oil and Environmental Conflicts" in Saliu Hassan A. (ed.), Nigeria Under Democratic Rule, 1999-2003, Vol. 2, Ibadan: Ibadan University Press. 82-83.

[11] Nyemutu, R. (n.d), "The State, Accumulation and Violence: The Politics of Environmental Security in Africa's Oil Producing Areas", Nigeria Institute of Social and Economic Research (NISER) Monograph Series, No. 17, 33.

[12] Azaiki, S. (2006), Oil, Politics and Blood: The Niger-Delta Story. Ibadan (Y-Books), A Division of Associated Bookmakers Nigeria Limited.

[13] Okani, I. (2011), NDDC: Politics of Survival", Daily Champion (Lagos) 25 January.

[14] Nwachukwu, C. (2008), Nigeria Loses N81 Billion to Delta Crisis. The Punch (Lagos) 21 March.

[15] Ekpo, Udeme (2004), The Niger Delta and Oil Politics. Lagos, International Energy Commissions Ltd.

[16] Akhakpe Ighodalo (2002), "Federal and Resource Control Agitations in Nigeria: Towards An Alternative Framework for Peace" in The Constitution: A Journal of Constitutional Development, Vol. 2, No. 3, March.

[17] Nsirimovu, A. (1994), The Massacre of an Oil Producing Community: The Umuechem Tragedy Revisited, Port Harcourt .

[18] Okani, I. "NDDC: Politics of Survival”, Daily Champion (Lagos), January 25, 2011. 
American Research Journal of History and Culture, Volume 1, Issue 1, 2015

ISSN 2379-2914

[19] Adejumobi, S. (2002), "Ethnic Militia Groups and the National Question in Nigeria", A paper presented to the Conference on Urban Violence, Ethnic Militia and the Challenge of Democratic Consolidation in Nigeria, April 23 - 26, Lagos, Nigeria. 